\title{
Late Quaternary history of northern Russia and adjacent shelves - a synopsis
}

\author{
EILIV LARSEN, SVEND FUNDER AND JÖRN THIEDE
}

\section{BOREAS}

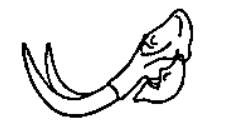

\begin{abstract}
Larsen, E., Funder, S. \& Thiede, J. 1999 (March): Late Quaternary history of northern Russia and adjacent shelves - a synopsis. Boreas, Vol. 28, pp. 6-11. Oslo. ISSN 0300-9483.

This synopsis highlights some of the main results presented in this issue of Boreas. The collection of papers deals with ice sheet reconstruction in space and time, isostatic and eustatic response to deglaciation, land to shelf sediment interaction, and Eemian and Holocene environmental variations. The most significant new results are that the last glacial maximum of the Kara Sea and Barents Sea ice sheets were both much smaller and much older than in most previous hypotheses. This puts new constraints on, for example, climate and ice sheet linkages, ice sheet interactions (Scandinavian-Barents Sea-Kara Sea), and land-ocean riverine input through time.
\end{abstract}

Eiliv Larsen, Geological Survey of Norway, P.O. Box 3006, N-7002 Trondheim, Norway; Svend Funder, Geological Museum, University of Copenhagen, Østervoldgade 5-7, DK-1350 Copenhagen, Denmark; Jörn Thiede, Alfred-Wegener-Institute for Polar and Marine Research, Columbusstrasse, D-27568 Bremerhaven, Germany. E-mail: eiliv.larsen@ngu.no; received 1st December 1998, accepted 14th January 1999.
On the wide North-Eurasian Arctic oceanic shelf large ice sheets have formed, grown and declined repeatedly during the Late Cenozoic ice ages, and during their culmination invaded the northern Russian and Siberian lowland to a distance of hundreds of kilometers from the present coastline. The shelf-bound Barents and Kara Sea ice sheets were controlled by sea-level change in addition to precipitation and temperature, and in turn controlled the northwards drainage from large parts of the Eurasian continent.

This has been a major factor in global change, and in Russia it has been established knowledge for a long time (e.g. Yakovlev 1956). However, not until Denton \& Hughes (1981) published their book on the last great ice sheets did the concept of shelf-bound glaciation receive widespread acceptance in western literature. Since then, estimates on the sizes and ages of these ice sheets have varied greatly, from the Late Weichselian amalgamation of ice domes extending from the British Isles in the west to the Lena river in the east and reaching down to some $60^{\circ} \mathrm{N}$, as suggested by Grosswald (1980) to the much smaller ice sheets, reaching only the western Kara Sea in the east and down to $65^{\circ} \mathrm{N}$ in the south, as advocated by Biryukov et al. (1988) and Faustova \& Velichko (1992).

The papers in this volume present new data, onshore and offshore, on the history of the north-Eurasian and Scandinavian ice sheets, especially during the Weichselian. An overview of new results on the Late and Early Weichselian ice distributions is given in the concluding paper by Svendsen et al. (1999), and more detailed accounts are given in a series of papers covering areas from the Laptev Sea in the east to Arkhangelsk in the west. Another group of papers deals with sea level and environmental change in the Late Weichselian and the Holocene. In this synopsis we highlight some of the main results in chronological order and point to some uncertainties and unsolved problems.

Figure 1 gives an overview of stratigraphic nomenclature used in different papers in the volume. Figure 2 depicts major geological occurrences discussed in the papers, while Figure 3 shows their location.

\section{The last interglacial}

Eemian marine and estuarine sediments are exposed along the large rivers of northern Russia, from Kola in the west to Taymyr in the east. They were deposited during the warm part of the last interglacial, and are easily identified by their warm boreal benthic faunas. In our work they have served as an important marker horizon to delimit the lower boundary of the overlying Weichselian sediments (Larsen et al. 1999; Mangerud et al. 1999).

The warm Eemian climate in the Eurasian north is also evidenced by more northerly limits for deciduous trees in a pollen diagram from northern Finland, which depicts the whole interglacial cycle beginning with open birch forests passing into temperature-optimal alder-pine vegetation, and ending with spruce forest growing on acidified soils (Saarnisto et al. 1999).

Sediment cores from marine parts of the Eurasian Arctic shelves have not yet reached Eemian deposits, mainly because of the inability of available coring techniques to penetrate thick glacial sequences or sea floors with submarine permafrost. Only in the region of the Lomonosov Ridge, located at some distance from 


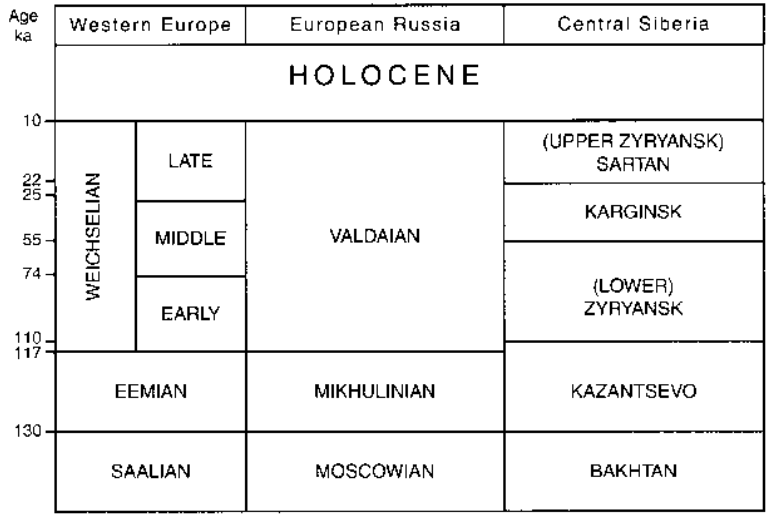

Fig. 1. Stratigraphic nomenclature as used by various authors in the present issue of Boreas.

the Eurasian Arctic shelf, and the adjacent deep-sea basins has anyone succeeded in recovering sediment cores with excellent Eemian records. They rest on deposits of an obviously very important glacial event linked to O-isotope stage 6 (Spielhagen et al. 1997). The O-isotope data and occurrences of planktonic foraminifera suggest that the Eemian Arctic Ocean was not as warm as during the Holocene.

\section{The last glacial}

\section{Permafrost and glaciation}

Permafrost and buried glacier ice has played and plays an important role in the study area, and more so further east. Along the Markhida line, extending from the Timan ridge to the Ural mountains, it has been shown that the morphological expression of ice-marginal features grows progressively fresher from west to east, although all evidence suggests that deposits constituting the end moraine zone are of the same age (Fig. 3 and Astakhov et al. 1999; Mangerud et al. 1999). This has been attributed to permafrost and buried glacier ice having survived much longer in the east compared to the west, emphasizing that caution should be exerted when using landscape maturity as an indicator of relative age when considering landforms in regions crossing climatic boundaries (Astakhov et al. 1999). In many cases melting and subsequent infilling of local ponds resulted in inversion of the landscape, causing original lows to stand out now as highs in the landscape (Astakhov et al. 1999; Larsen et al. 1999).

The surface profile of a glacier is dependent on the substrate, and a reconstruction of the glacier reaching the Markhida line suggests it to have had a very low profile to the west over thick sedimentary substrate, whereas the reconstruction indicates a steeper profile near the Ural mountains (Tveranger et al. 1999). This is not without complications, since permafrost in the substrate alters the rheologic properties, causing the surface profile to become steeper, except perhaps at brief intervals when a lowering of the profile near the ice margin may take place due to subglacial melting of the permafrost. This presumably would not significantly lower the profile further up-ice.

In many cases the terminal moraines of ice sheets can be followed to the submarine regions, where they often become very difficult to trace. The extension of the ice sheets to or across the shelf edge therefore remains an enigma. The same applies to the occurrence of permafrost, which is of glacial origin and which is known to occur in wide regions of northern Eurasia extending onto the adjacent Arctic shelves (Kassens et $a l$. in press). How far offshore and into what water depths submarine permafrost can be expected remains to be explored.

\section{Early to Middle Weichselian}

Among the most significant results of the recent work is the demonstration that glaciation on the Kara Sea shelf culminated before the Late Weichselian, as indicated earlier from western Siberia by Astakhov (1992). This has now been shown from the Pechora basin (Astakhov et al. 1999; Mangerud et al. 1999) and Taymyr (Möller et al. 1999), as summarized by Svendsen et al. (1999).

In European Russia the well-known Markhida moraine on the lower Pechora has now given its name to an ice marginal line (Astakhov et al. 1999; Mangerud et al. 1999; Svendsen et al. 1999), which has been mapped out, partly from air photos, for a distance of more than $700 \mathrm{~km}$, crossing the Pechora basin from the polar Urals to the west side of the Timan Ridge (Fig. 3 and Astakhov et al. 1999). Ice-directional features show unequivocally that the ice came from the Kara Sea in the northeast, except perhaps in the western part near the Timan ridge. The dating of this moraine has met with many problems, but based on a large number of 14C and OSL age estimates, Mangerud et al. (1999) now suggest that it lies within the interval 45-60 ka in the Middle Weichselian. A three-dimensional ice sheet reconstruction suggests that the ice was thin, less than $200 \mathrm{~m}$ thick, and mobile (Tveranger et al. 1999).

Another major finding is the traces of the Komi Lake (Astakhov et al. 1999; Mangerud et al. 1999), a large lake that occupied the Pechora lowlands for some time within the 55-80 ka interval, presumably dammed by ice behind the Markhida line to the north (Astakhov et al. 1999). Although the possibility of the damming of the northwards-flowing Russian rivers during the ice ages has been discussed extensively, the demonstration of the Komi Lake is probably the first positive identification and dating of such a lake basin in northern Eurasia. Whether the lake drained southwards into the Caspian or northwards into the Barents Sea is as yet uncertain (Astakhov et al. 1999).

On Taymyr at the eastern extremity of the Kara Sea, 


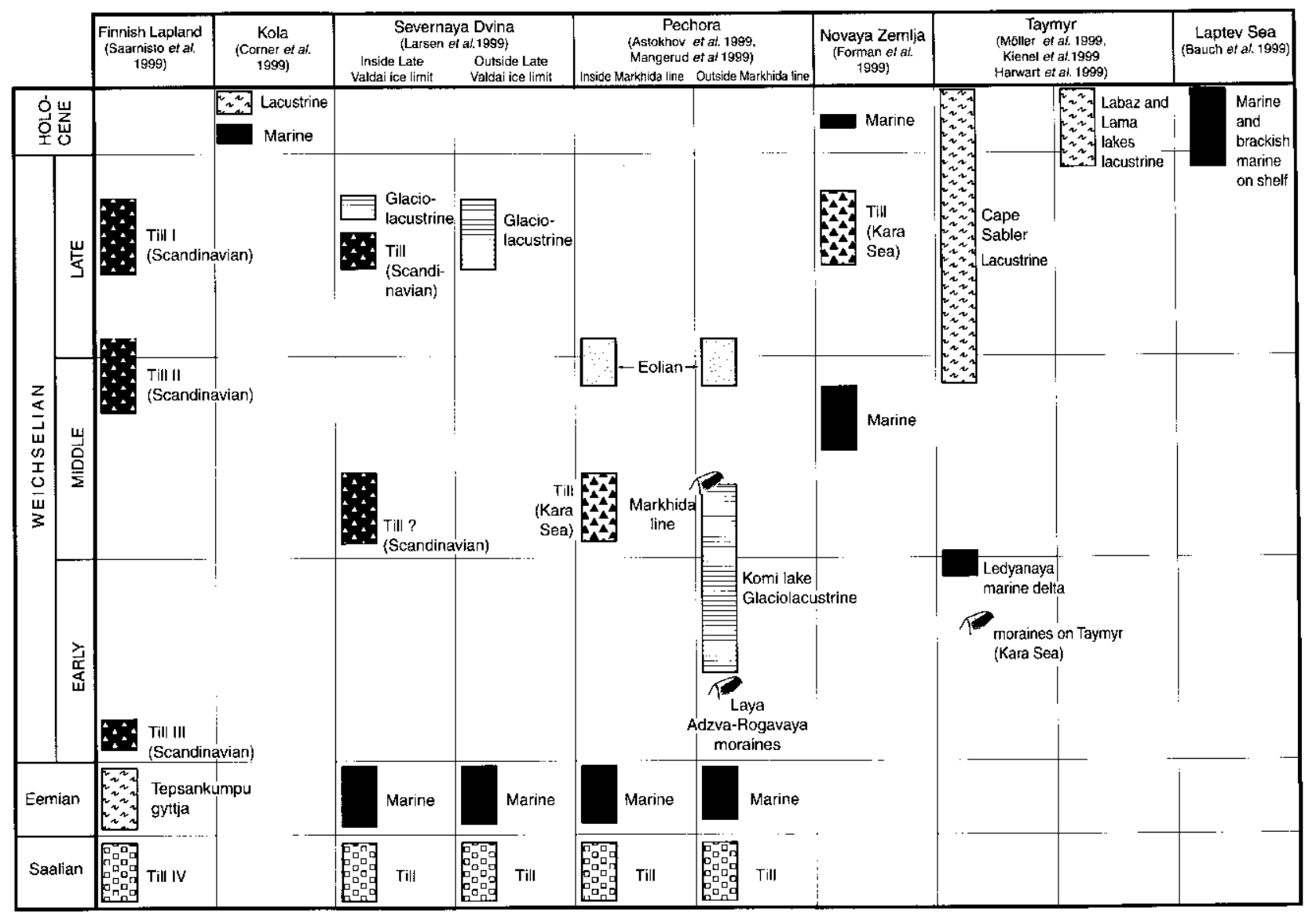

Fig. 2. Major geological occurrences in different areas discussed in the papers in this volume.

NW-SE trending ice marginal lines probably mark the maximum extension of the Kara Sea ice sheet in Middle-Late Pleistocene times (Isayeva 1984). A minimum age for the most advanced of these lines has now been provided by a large marine delta exposed along the Ledyanaya River, and built into the basin of what is now the Taymyr Lake (Möller et al. 1999). The delta is probably deglacial and related to the decline from the maximum extension of the Kara Sea ice over the central parts of Taymyr. Based on radiocarbon and ESR dating, an Early to Middle Weichselian age is tentatively suggested by Möller et al. (1999), although a Late Saalian age cannot be excluded. The minimum age is confirmed by the Cape Sabler sedimentary succession, a $c .25 \mathrm{~m}$-thick package of laminated lake sediments, reflecting near continuous and undisturbed lacustrine sedimentation in the Taymyr Lake basin from c. $39 \mathrm{ka} \mathrm{BP}$ to the present (Möller et al. 1999).

The new results, therefore, show that in both European Russia and central northern Siberia, the maximum Late Pleistocene glaciation was attained well before the Late Weichselian, i.e. out of phase with the global glacial maximum at c. $20 \mathrm{ka}$. The available dates indicate that the Early-Middle Weichselian Kara ice sheet may have reached Taymyr in the east while it invaded the northern part of European Russia in the west, as depicted by Svendsen et al. (1999). However, it should be mentioned that in neither of the two areas is the glaciation maximum dated accurately (Mangerud et al. 1999; Möller et al. 1999). If taken literally, the dating results could indicate that the Ledyanaya delta and the Taymyr ice marginal line is older than the Markhida line at Pechora, and therefore that maximum glaciation was not coincident along the margin of the Kara Sea ice sheet.

What happened in the Barents Sea and in Scandinavia at the time when the Kara Sea ice sheet attained its maximum? In southern Scandinavia there is evidence to suggest large-scale glaciation in Middle Weichselian times, which could be contemporaneous with the large Kara Sea ice sheet (e.g. Houmark Nielsen, in press), whereas the Barents Sea ice sheet may have only influenced a narrow strip of the Russian landmass near the Timan ridge. Therefore, the problem of the interaction between the three ice sheets ranks high on the agenda for future fieldwork. 


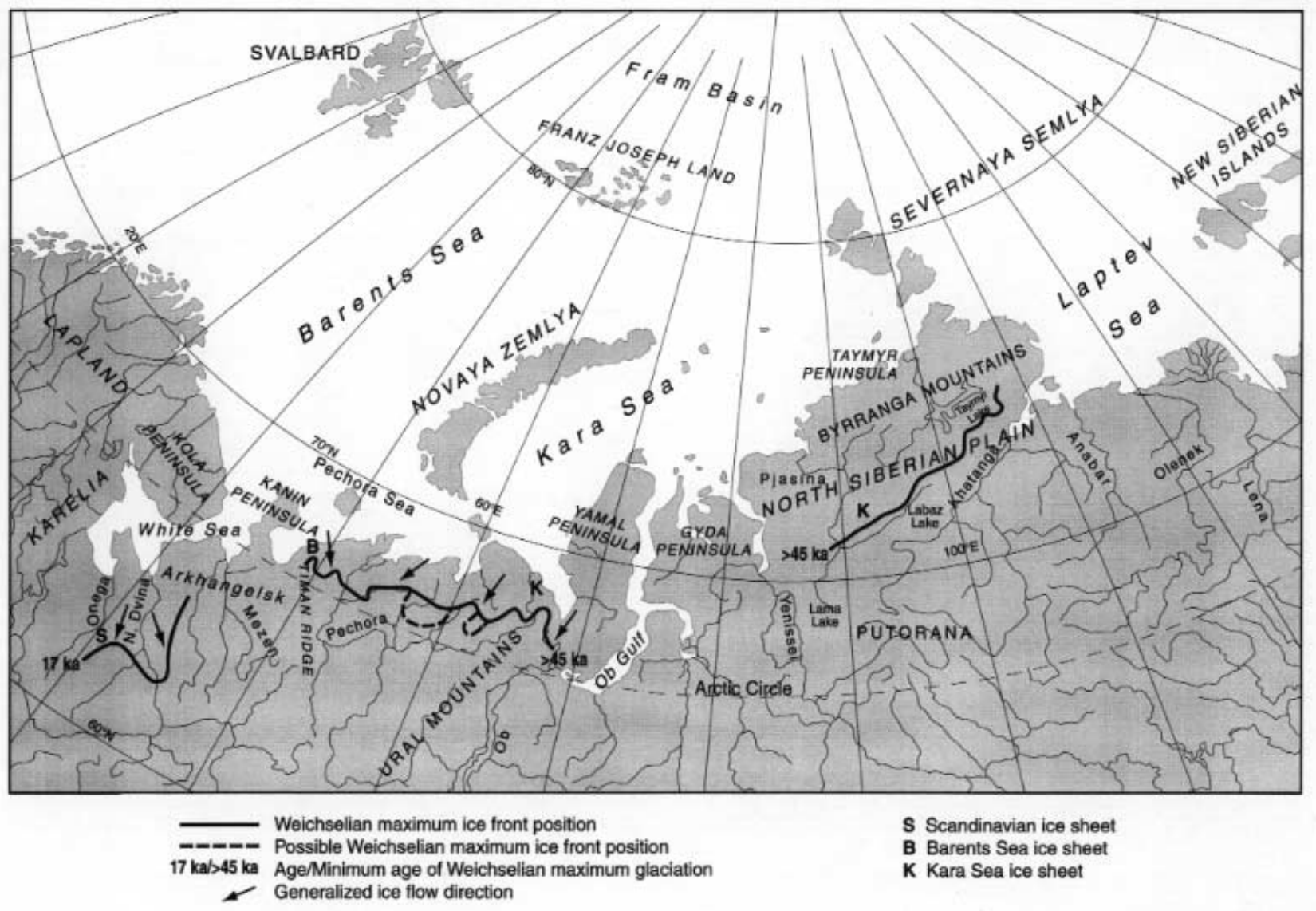

Fig. 3. Map showing the combined study area from papers in this issue of Boreas. The ice marginal limits with assigned ages are from the papers by Astakhov et al. (1999), Larsen et al. (1999), Mangerud et al. (1999), Möller et al. (1999) and Svendsen et al. (1999).

\section{Late Weichselian}

Glacial terrestrial sediments dated with certainty to the Late Weichselian have only been identified along the Severnaya Dvina, where a tongue from the Scandinavian ice sheet penetrated southeastwards in the wide river basin. OSL dates indicate that the ice sheet in this area attained its maximum position after $17 \mathrm{ka}$ (Larsen et al. 1999), i.e. several millennia after the maximum was attained in the SW of the ice sheet (Sejrup et al. 1994). In the Pechora basin no glacial sediments from this period have been identified, implying that northeast Russia was ice free (Mangerud et al. 1999). In the Kara Sea area preliminary results from northern Taymyr indicate that a small shelf-bound ice sheet could possibly have existed in the Late Weichselian, but it did not expand onto the Siberian mainland. However, this idea needs more careful study. In any case the results imply that the Kara Sea ice sheet was smaller much than in the Early-Middle Weichselian (Svendsen et al. 1999).

Thus, while there is firm evidence for the existence of a large Scandinavian ice sheet, and ambiguous evidence for a small Kara Sea ice sheet, there is as yet no evidence for the existence of a Barents Sea ice sheet in this period in the northwestern parts of Russia.

The central Arctic Ocean records from the last glacial maximum suggest full glacial conditions with a substantial sea-ice cover and important ice-rafting events (Spielhagen et al. 1997). However, in the Fram Strait and immediately to the north of Svalbard, occurrences of subpolar planktonic foraminifera in sediments belonging to the last glacial maximum suggest the advection of substantial amounts of Atlantic water, potentially even seasonally open surface waters (Hebbeln \& Wefer 1997; Kniess 1998).

\section{The Late-Glacial and the Holocene}

Based on dating of Holocene raised shorelines in northern Novaya Zemlya, it is suggested that the Barents Sea ice sheet either melted at $c .13 \mathrm{ka}$ or was thin (Forman et al. 1999). A Holocene shore line diagram from just within the Younger Dryas ice sheet boundary in the western Kola peninsula shows the 
Tapes transgression to be somewhat lower than predicted from previously published shore line diagrams (Corner et al. 1999). Whether this is due to inaccuracies in dating of the shorelines or differences in glacioisostatic response in different areas has yet to be demonstrated. In the western Laptev Sea, outside the limit of Late Pleistocene glaciation(s), eustatic sea level rise is recorded in three cores from the shallow shelf beginning at $c .12 \mathrm{ka}$ and reaching stability at $c .6 \mathrm{ka}$ (Bauch et al. 1999). Holocene environmental changes on Taymyr are discussed in two papers that demonstrate the northward oscillation of the tree line in Early-Middle Holocene times (Harwart et al. 1999; Kienel et al. 1999). On the adjoining continental shelves and the Arctic Ocean, mapping of Holocene clay and heavy mineral distribution show sediment pathways, identifying the large Russian rivers as main sediment sources to the adjoining shelves and the Arctic Ocean (Peregovich et al. 1999; Washner et al. 1999). Correlation with the environmental changes on the continent, including ice sheet variations, is, however, somewhat premature.

\section{Ice sheet interactions}

An important aspect of the results presented in this volume is the new information on the interaction between the three large Eurasian ice sheets, the Scandinavian, Barents Sea and Kara Sea ice sheets. Earlier syntheses of the behavior of these ice sheets have generally postulated that they grew and waned in phase (e.g. Denton \& Hughes 1981). The results presented in this volume have, as noted by Svendsen et al. (1999), changed this concept. In Early-Middle Weichselian times when the Kara Sea ice sheet in the east reached its culmination, the Scandinavian ice sheet in the west was smaller than its maximum size. In the Late Weichselian, on the other hand, when the Scandinavian ice sheet culminated, the Kara Sea ice sheet was small or absent. This pattern indicates that moisture supply from the west penetrated further to the east in Early-Middle Weichselian time than later in the ice age. However, the role of the Barents Sea ice sheet in this history is still unresolved. At its western margin, this ice sheet experienced two Weichselian maxima, in Middle and Late Weichselian times (Landvik et al. 1998; Mangerud et al. 1998). However, its eastern and southern limits during Late Weichselian time remain uncertain. From the results presented in this volume the region between the Kola peninsula and Novaya Zemlya may hold the clues to interactions between the three ice sheets in time and space. The understanding of the interaction between the ice sheets is vital for our understanding of climate/ice sheet mechanisms, and studies in this area rank high on the agenda for future work.
Acknowledgements. - This is a contribution to the European Community project Ice Sheets and Climate in the Eurasian Arctic at the Last Glacial Maximum (Eurasian Ice Sheets, contract ENV4CT97-0563) and to the European Science Foundation Programme Quaternary Environment of the Eurasian North (QUEEN). Figures were prepared by L. Belhage and M. Diman. D. Mickelson corrected the English language.

\section{References}

Astakhov, V. I. 1992: The last glaciation in West Siberia. Sveriges Geologiska Undersökning, Series Ca. 81, 21-30.

Astakhov, V. I., Svendsen, J. I., Matioushkov, A., Mangerud, J., Maslenikova, O. \& Tveranger, J. 1999: Marginal formations of the last Kara and Barents ice sheets in northern European Russia. Boreas 28, 23-45.

Bauch, H. A., Kassens, H., Erlenkeuser, H., Grootes, P. M. \& Thiede, J. 1999: Depositional environment of the Laptev Sea (Arctic Siberia) during the Holocene. Boreas 28, 194-204.

Biryukov, V. V., Faustova, M. A., Kaplin, P. A., Pavlidis, Y. A., Romanova, E. A. \& Velichko, A. A. 1988: The palaeogeography of Arctic Shelf and coastal zone of Eurasia at the time of the last glaciation. Palaeogography, Palaeoclimatology, Palaeoecology $68,117-125$.

Corner, G. D., Yevzerov, V. Y., Kolka, V. \& Møller, J. J. 1999: Isolation basin stratigraphy and Holocene relative sea-level change at the Norwegian-Russian border north of Nikel, northwest Russia. Boreas 28, 146-166.

Denton, G. H. \& Hughes, J. (eds.) 1981: The Last Great Ice Sheets. 484 pp. John Wiley \& Sons, Inc., New York.

Faustova, M. A. \& Velichko, A. A. 1992: Dynamics of the last glaciation in northern Eurasia. Sveriges Geologiska Undersökning Ser. Ca 81, 113-118.

Forman, S. L., Lubinski, D. J., Zeeberg, J. J., Polyak, L., Miller, G. H., Matishov, G. \& Tarasov, G. 1999: Postglacial emergence and Late Quaternary glaciation on northern Novaya Zemlja, Arctic Russia. Boreas 28, 133-145.

Grosswald, M. G. 1980: Late Weichselian ice sheets of Northern Eurasia. Quaternary Research 13, 1-32.

Harwart, S., Hagedorn, B., Melles, M. \& Wand, U. 1999: Lithological and biochemical properties of Lama Lake as indicators for the late Pleistocene and Holocene ecosystem development of the southern Taymyr Peninsula, Central Siberia. Boreas 28, 167180.

Hebbeln, D. \& Wefer, G. 1997: Late Quaternary paleoceanography in the Fram Strait. Paleoceanography 12, 65-78.

Houmark-Nielsen, M.: A lithostratigraphy of Weichselian glacial and interstadial deposits in Denmark. Bulletin of the Geological Society of Denmark (In press).

Isayeva, L. L. 1984: Late Pleistocene glaciation of North-Central Siberia. In Velichko, A. A. (ed.): Late Quaternary Environments of the Soviet Union, 21-30. University of Minnesota Press, Minneapolis.

Kassens, H., Bauch, H., Dmitrenko, I., Eicken, H., Hubberten, H. -W., Melles, M., Thiede, J. \& Timokhov, L. In press: Land Ocean Systems in the Siberian Arctic: Dynamics and History. Springer, Berlin.

Kienel, U., Siegert, C. \& Hahne, J. 1999: Late Quaternary paleoenvironmental reconstruction from a permafrost sequence (NorthSiberian Lowland, SE Taymyr Peninsula) - a multidisciplinary case study. Boreas 28, 181-193.

Kniess, J. In press: Spätquartäre Paläoumweltbedingungen am nördlichen Kontinentalrand der Barents- und Kara-See. Eine MultiParameter-Analyse. Berlin Polarforschung.

Landvik, J. Y., Bondevik, S., Elverhøi, A., Fjeldskaar, W., Mangerud, J., Siegert, M. J., Salvigsen, O., Svendsen, J. I. \& Vorren, T. O. 1998: The last glacial maximum of Svalbard and the 
Barents Sea area: Ice sheet extent and configuration. Quaternary Science Reviews 17, 43-75.

Larsen, E., Lyså, A., Demidov, I., Funder, S., Houmark-Nielsen, M., Kjær, K. H., \& Murray, A. S. 1999: Age and extent of the Scandinavian ice sheet in northwest Russia. Boreas 28, 115132.

Mangerud, J., Dokken, T., Hebbeln, D., Heggen, B., Ingolfson, O., Landvik, J. Y., Mejdahl, V., Svendsen, J. I., \& Vorren, T. 1998: Fluctuations of the Svalbard-Barents Sea ice sheet during the last 150000 years. Quaternary Science Reviews 17, 11-42.

Mangerud, J., Svendsen, J. I. \& Astakhov, V. 1999: The age and extent of the Barents and Kara Sea ice sheets in Northern Russia. Boreas 28, 46-80.

Möller, P., Bolshiyanov, D. Y. \& Bergsten, H. 1999: Weichselian geology and paleoenvironmental history of the central Taymyr Peninsula, Siberia, indicating no glaciation during the last glacial maximum. Boreas 28, 92-114.

Peregovich, B., Hoops, E., \& Rachold, V. 1999: Sediment transport to the Laptev Sea (Siberian Arctic) during the Holocene - evidence from the heavy mineral composition of fluvial and marine sediments. Boreas 28, 205-214.

Saarnisto, M., Eriksson, B. \& Hirvas, H. 1999: Tepsankumpu revisited - pollen evidence of stable Eemian climates in Finnish Lapland. Boreas 28, 12-22.

Sejrup, H. P., Haflidason, H., Aarseth, I., King, E., Forsberg, C. F.,
Long, D. \& Rokoengen, K. 1994: Late Weichselian glaciation history of the northern North Sea. Boreas 23, 1-13.

Spielhagen, R. F., Bonani, G., Eisenhauer, A., Frank, M., Frederichs, T., Kassens, H., Kubik, P. W., Mangini, A., NørgaardPedersen, N., Nowaczyk, N. R., Schäper, S., Stein, R., Thiede, J., Tiedemann, R. \& Wahsner, M. 1997: Arctic Ocean evidence for late Quaternary initiation of northern Eurasian ice sheets. Geology 25, 783-786.

Svendsen, J. I., Astakhov, V. I., Bolshiyanov, D. Yu., Demidov, I., Dowdeswell, J. A., Gataullin, V., Hjort, C., Hubberten, H. W., Larsen, E., Mangerud, J., Melles, M., Möller, P., Saarnisto, M. \& Siegert, M. J. 1999: Maximum extent of the Eurasian ice sheets in the Barents and Kara Sea region during the Weichselian. Boreas 28, 234-242.

Tveranger, J., Astakhov, V., Mangerud, J. \& Svendsen, J. I. 1999: Surface form of the last Kara ice sheets as inferred from its southwestern marginal features. Boreas 28, 81-91.

Wahsner, M., Mueller, C., Stein, R., Ivanov, G., Levitan, M., Shelekhova, E. \& Tarasov, G. 1999: Clay mineral distributions in surface sediments from the Central Arctic Ocean and the Eurasian continental margin as indicator for source areas and transport pathways - A synthesis. Boreas 28, 215-233.

Yakovlev, S. A. 1956: The fundamentals of the Quaternary geology of the Russian Plain. VSEGEI 17, 314 pp. Moscow, in Russian. 